Yuzuncu Y1l University
Journal of Agricultural Science
http://dergipark.gov.tr/yyutbd

Research Article

\title{
Cost Efficiency Status of Rice Farmers Participating in IFAD/VCD Programme in Niger State of Nigeria
}

\author{
Mohammed Sanusi SADIQ*1, Invinder Paul SINGH ${ }^{2}$, Muhammad Makarfi AHMAD ${ }^{3}$ \\ ${ }^{1}$ Federal University Dutse, Faculty of Agric., Dep. of Agricultural Economics and Extension, Dutse, Nigeria \\ ${ }^{2}$ S.K. Rajasthan Agricultural University, College of Agriculture, Dep. of Agricultural Economics, Bikaner, India \\ ${ }^{3}$ Bayero University Kano, Department of Agricultural Economics and Extension, P.M.B. 3011, Kano, Nigeria \\ ${ }^{1}$ https://orcid.org/0000-0003-4336-57231 ${ }^{2}$ https://orcid.org/0000-0002-1886-5956 ${ }^{3} \mathrm{https} / / /$ orcid.org/0000-0003-4565-0683 \\ *Corresponding author e-mail: sadiqsanusi30@gmail.com
}

\section{Article Info}

Received: 05.06.2020 Accepted: 21.05.2021

Online Published 30.06.2021

DOI: 10.29133 yyutbd. 748367

\section{Keywords}

Cost efficiency,

Frontier,

IFAD,

Nigeria,

Rice,

Stochastic.

\begin{abstract}
This research empirically determined the cost efficiency of the farmers that participated in the IFAD/VCD programme in Niger State of Nigeria. The study elicited cross-sectional data of the 2018 cropping season viz. wellstructured questionnaire complemented with interview schedule from a sample size of 110 respondents selected through a multi-stage sampling technique. The sampled data were analysed using the stochastic cost frontier model. The empirical evidence showed that none of the farmers was on the cost frontier surface i.e. inability to attain optimal minimum cost in the cultivation of rice in the studied area. The identified significant idiosyncratic variables militating against cost efficiency were the poor health status of the farm family which led to the extra cost incurred in labour substitution and diseconomies of scale due to their small-scale mode of operation. Therefore, the study recommends that the policymakers should sensitize the farmers on the importance of health preventive measures and should endeavour to improve on the existing basic health centres both in human capital and logistics. In addition, the farmers should be encouraged to explore cooperative marketing so as to take advantage of the bulk discount in input purchase and have bargaining power in the marketing of their output, thus tackling the problem of diseconomies of scale in their farm operations.
\end{abstract}

\section{Nijerya'nınNijerDevletinde IFAD / VCD ProgramınaKatılanPirinçÇiftçilerininMaliyetVerimliliği Durumu}

\section{Makale Bilgileri}

Geliș: 05.06.2020

Kabul: 21.05.2021

Online Yayinlanma 30.06.2021

DOI: 10.29133 /yyutbd.748367

\section{Anahtar Kelimeler}

Maliyet etkinliği,

Sinir,

IFAD,

Nijerya,

Pirinç,

Stokastik.
Öz: Bu araştırma, Nijerya'nın Nijer Eyaleti'ndeki IFAD / VCD programına katılan çiftçilerin maliyet etkinliğini ampirik olarak belirlemiştir. Çalışma, çok aşamalı bir örnekleme tekniği ile 110 katılımcıdan oluşan bir örnekleme büyüklüğünden seçilen röportaj usulü ile tamamlanan iyi yapılandırılmış bir anket ile 2018 üretim sezonunun çapraz kesit verilerini ortaya çıkardı. Örneklenen veriler, stokastik maliyet sınır modeli kullanılarak analiz edilmiştir. Ampirik kanıtlar, çiftçilerden hiçbirinin maliyet sınırında olmadığını, yani incelenen alanda pirinç ekiminde ideal minimum maliyete ulaşılamadığını göstermiştir. Maliyet verimliliğine engel olan belirgin kendine özgü değişkenler, iş̧̧i ikamesinde katlanılarak ekstra maliyete yol açan çiftlik ailesinin kötü sağlık durumu ve küçük ölçekli çalışma biçimleri nedeniyle ölçek ekonomileriydi. Bu nedenle çalışma, politika yapıcıların çiftçileri sağlığı koruyucu önlemlerin önemi konusunda duyarlı hale getirmelerini ve hem beşeri sermaye hem de lojistik alanlarda mevcut temel sağlık merkezlerini iyileştirmek için çaba göstermeleri 
gerektiğini önermektedir. Buna ek olarak, çiftçiler, girdi satin alımında toplu indirimden yararlanmak ve çıktılarının pazarlanmasında pazarlık gücüne sahip olmak ve böylece çiftlik faaliyetlerindeki ölçek ekonomisi sorununu çözmek için kooperatif pazarlamayı keşfetmeye teşvik edilmelidir.

\section{Introduction}

Farming in Nigeria has been on the subsistence scale given that the bulk of the producers are resource-poor. The most viable chance of breaking the vicious cycle of poverty affecting these farmers is to transit them to a sustainable farming system. The imperfection in the markets has made it difficult for these resource-poor farmers to keep-up with the going concern of their firm enterprises, thus worsening their livelihood and food security of the studied area in particular and the country in general.

The essence of the IFAD-VCD programme is to secure the livelihood of the rural populace particularly the weaker section so that they can break the vicious cycle of poverty. The feasibility of Nigeria's economic growth and development depends largely on empowering the rural poor communities viz. identifications of their needs and implementations of broad based agricultural and rural development initiatives. The failure to sustain most of the agricultural projects in the studied area is not due to lack of interest of the target groups in farming but rather poor productivity of capital investment which is not remunerative to sustain the livelihood of the beneficiaries more less the business going concern. The rationality of any farmer in enterprise allocation solely lies on the cost of production which is a function of the market prices of inputs and outputs, a condition which the farmers have little or no control over. Thus, the business concern of a farmer to continue or pull-out from the business of crop farming depends on cost.

For the study area to achieve rice food security and alleviate poverty which is the goal of the programme, it is important to identify the factors that affect farmers' cost efficiency in rice production and further measure the extent to which they limit the cost efficiency of the decision units. In view of the foregoing, this research was conceptualized with the aim of having a clearer understanding of cost efficiency and the feasibility of predicting the allocative efficiency of the target groups in the studied area.

Therefore, for the IFAD programme not to be a fail project, it becomes very imperative to determine the cost efficiency status of the farmers participating in the programme in Niger State of Nigeria using the parametric cost frontier model. Ogundariet al.(2006); Paudel and Matsuoka (2009); and, Sadiq and Singh (2016) have opined that improvement in the understanding of farmers' status of cost efficiency and its interlink with their idiosyncratic covariates would greatly assist policymakers in promulgating efficiency enhancing policies as well as judging the efficiency of the current and previous reforms.

\section{Materials and Methods}

Niger State is located in Nigeria a sub of Africa continent and it lies between latitudes $8^{\circ} 20^{\prime} \mathrm{N}$ and $11^{\circ} 30^{\prime} \mathrm{N}$ of the equator and longitudes $3^{\circ} 30^{\prime} \mathrm{E}$ and $7^{\circ} 20^{\prime} \mathrm{E}$ of the Greenwich Meridian time. The vegetation of the state is northern guinea savannah with sparse of southern guinea savannah around Mokwa Local Government Area (LGA). Agriculture is the major occupation in the study area and it's complemented with civil service jobs, artisanal, craftwork, Ayurveda medicines and petty trade. The study made use of a multi-stage sampling technique to draw a sample of 110 active participants in the programme. In the state, the programme is currently mounted in five (5) LGAs with Agricultural Zone A (Bida) and C (Kontagora) having two LGAs each namely Bida and Katcha; and, Wushishi and Kontagora, respectively, while Zone B has one participating LGA viz. Shiroro. In the first stage, Katcha was randomly selected from Zone A while Shiroro LGA was automatically selected being the only participating LGA in Zone B. Wushishi LGA due to its comparative advantage in rice production throughout the year owing to the presence of Tungan Kawo irrigation dam was purposively selected from the Agricultural Zone C. In the second stage, two villages were randomly selected from each of the chosen LGAs. Thereafter, two active co-operative associations from each of the selected villages were randomly selected. It is worth to note that Microsoft excel inbuilt random sampling mechanism 
was used for the random selections of the villages and the co-operative associations. In the last stage, using the sampling frame obtained from IFAD/VCD office (Table 1), the Cochran's formula was used to determine the representative sample size. Thus, a total of 110 active rice farmers form the sample size for the study. A well-structured questionnaire complemented with interview schedule was used to elicit information from the respondents during the 2018 cropping season, and stochastic cost frontier model was used to analyse the collected data. The Cochran's formula used is shown below:

$n_{a}=\frac{n_{r}}{1+\frac{\left(n_{r}-1\right)}{N}}$

$n_{r}=\frac{(1.96)^{2} p q}{e^{2}}$

Where:

$n_{a}=$ adjusted sample size for finite population

$n_{r}=$ sample size for infinite population

$N=$ population size

$\mathrm{Np}=$ proportion of population having a particular characteristic

$\mathrm{Nq}=1-\mathrm{p}$

$e^{2}=$ error gap $(0.07)$

Thus, $\mathrm{p}=0.40$ and $\mathrm{q}=1-0.60=0.40$

Table 1. Sampling frame of participating farmers

\begin{tabular}{|c|c|c|c|c|}
\hline LGAs & Villages & Co-operative Associations & SF & SS \\
\hline \multirow{4}{*}{ Katcha } & Baddegi & Managi Badeggi Farmers CMPS & 24 & 10 \\
\hline & & Aminci Ebanti Twaki CMPS Ltd & 25 & 10 \\
\hline & Edostu & Edotsu Co-Operative Credit \& Marketing CMPS & 25 & 10 \\
\hline & & Edotsu JinjinWugakunYema CMPS & 25 & 10 \\
\hline \multirow{4}{*}{ Shiroro } & Baha & Baha Abmajezhin Cooperative Multi-Purpose Society Ltd & 15 & 7 \\
\hline & & Abwanubo Najeyi Development Association & 18 & 8 \\
\hline & Paigado & Paigado Achajebwa Development Farmers Soc. & 25 & 10 \\
\hline & & Paigado Farmers Cooperative Society Ltd & 25 & 10 \\
\hline \multirow{4}{*}{ Wushishi } & Bankogi & Bankogi Alheri Farmers Coop. Multipurpose Soc Ltd & 22 & 9 \\
\hline & & Bankogi GwariNasara CMPS & 16 & 7 \\
\hline & Kanko & Kanko Arewa Farmers & 25 & 10 \\
\hline & & $\begin{array}{l}\text { Kanko Unguwar Ndakogi Cooperative Multipurpose Society } \\
\text { Ltd }\end{array}$ & 25 & 10 \\
\hline Total & & & 270 & 111 \\
\hline
\end{tabular}

Source: IFAD-VCDP farmers' database, 2018.

Note: SF and SS mean sampling frame and sample size respectively.

\section{Material and Methods}

\subsection{Model specification}

Stochastic Cost Frontier Function: Following Battesse and Coelli (1995); Ogndari et al. (2006); Sadiq and Isah (2015); Sadiq and Singh (2016) and Sadiq and Samuel (2016), the adopted stochastic cost frontier (SCF) function is shown below:

$C_{i}=f\left(P_{i j}, Y_{i j} ; \beta\right)+\left(V_{i}+U_{i}\right)(i=1,2 \ldots . n)$

$C_{i}=$ Total production cost of the $\mathrm{i}^{\text {th }}$ farmer;

$P_{i}=$ Vector prices of the actual $\mathrm{j}^{\text {th }}$ inputs used by the $\mathrm{i}^{\text {th }}$ farmer;

$Y_{i}=$ Vector of the actual $\mathrm{j}^{\text {th }}$ output of the $\mathrm{i}^{\text {th }}$ farmer;

$\beta_{i}=$ parameter to be estimated; 
$V_{i}=$ Uncertainty which is beyound the control of the $\mathrm{i}^{\text {th }}$ farmer;and,

$U_{i}=$ Risk which is attributed to the error of the $\mathrm{i}^{\text {th }}$ farmer;

Positive sign preceded the composite error term because inefficiency is always assumed to increase cost.

Given the level of technology at the disposal of a technical unit, the cost efficiency is expressed as the ratio of the observed cost $\left(C^{b}\right)$ to the corresponding minimum cost $\left(C^{\mathrm{min}}\right)$, and it is given below:

$C_{e}=\frac{C^{b}}{C^{\min }}=\frac{f\left(P_{i j}, Y_{i j} ; \beta\right)+\left(V_{i}+U_{i}\right)}{f\left(P_{i j}, Y_{i j} ; \beta\right)+V_{i}}=\exp \left(U_{i}\right)$

Where $C_{e}$ is the cost efficiency and takes the value of $\geq 1$ with 1 defining cost efficient technical unit. The observed cost $\left(C^{b}\right)$ represents the actual total cost while the minimum $\operatorname{cost}\left(C^{\mathrm{min}}\right)$ represents the frontier total cost or the least total cost level.

The explicit form of the Cob-Douglas functional form of the SCF function is as follow:

$\ln C_{i}=\ln \beta_{0}+\sum \beta_{k} \ln P_{i j}+\beta_{l} \ln Y_{i j}+V_{i}+U_{i}$

Where $C_{i}=$ Total production cost of $i^{\text {th }}$ farmer; $P_{i}=$ Vector of unit prices of farm inputs used: $P_{1}=$ unit price of seed $(\AA / \mathrm{kg}), P_{2}=$ unit price of NPK fertilizer $(\AA / \mathrm{kg}), P_{3}=$ unit price of urea fertilizer ( $\$ / \mathrm{kg}$ ), $P_{4}=$ unit price of herbicides ( $\$ /$ litre), $P_{5}=$ unit price of human labour ( $\$ /$ man-day), $P_{6}=$ depreciation on capital items ( $)$, and $P_{7}=$ rental value of land ( $\$ /$ hectare); $Y_{i}=$ Farm output ( $\mathrm{kg}$ ) from $i^{\text {th }}$ farmer; $V_{i}=$ random variability in the production that cannot be influenced by the $i^{\text {th }}$ farmer also known as uncertainty; $U_{i}=$ deviation from maximum potential output attributable to cost inefficiency and also known as risk. $\beta_{0}=$ intercept; $\beta_{k}=$ vector of cost parameters to be estimated; $\beta_{l}=$ vector of output parameter to be estimated; $i=1,2,3 \ldots \ldots n$ farmers; $j=1,2,3 \ldots \ldots \ldots$ m inputs.

The inefficiency model is:

$U_{i}=\delta_{0}+\delta_{1} Z_{1}+\delta_{2} Z_{2} \ldots \ldots \ldots+\delta_{n} Z_{n}$

Where $Z_{1}=$ Educational level (year); $Z_{2}=$ Sickness of farm family member (number); $Z_{3}=$ Extension visit (number); $Z_{4}=$ Access to credit (yes $=1$, no $=0$ ); $Z_{5}=$ Age (year); $Z_{6}=$ Household size (number); $Z_{7}=$ Income (yes $=1$, no $=0$ ); $Z_{8}=$ Farm size (hectare); $Z_{9}=$ Farming experience (year); $Z_{10}=$ Non-farm income (yes $=1$, no $=0$ ); $Z_{11}=$ Language spoken (number); $\delta_{0}=$ intercept; and, $\delta_{1-n}=$ parameters to be estimated.

A Frontier version 4.1 was used for the stochastic cost efficiency estimation.

\section{Results}

\subsection{Cost efficiency of IFAD rice farmers}

A cursory review of the maximum likelihood estimates (MLE) of the stochastic cost frontier function showed the variance parameters viz. sigma and gamma (0.8631) to be different from zero at $10 \%$ degree of freedom. The implication of the significance of the sigma-squared and gamma indicate the goodness of fit of the specified SCF and the correctness of the composite error term; and the presence of the cost inefficiency, respectively. Therefore, it can be inferred that the differences in the cost efficiencies of the sampled farmers accounted for $86.31 \%$ variation in the total cost (Table 2). In addition, the calculated log-likelihood ratio test being greater than the tabulated $\mathrm{Chi}^{2}$ indicates the presence of one-sided error, thus an indication that the traditional response function (OLS) cannot fit the data (Table 3).

Furthermore, with the exception of seed price all the parameter estimates (capital and labour costs) induced monotonicity in the cost function as evident by the positive sign associated with their coefficients (Table 2). The non-monotonicity of the seed price coefficient is an indication of congestion in the use of seed input which owes to the provision of subsidy, thus the negative sign associated with 
the seed price coefficient. The empirical evidence showed that the total cost incurred in the production of rice was influenced by seed cost, costs of agrochemicals, rental cost and rice output as indicated by their respective probability levels which were different from zero at $10 \%$ degree of freedom.

The negative significance of the seed cost coefficient implied that improved rice seed varieties were sold to the farmers at subsidized price, thus the non-monotonicity of the total cost despite increase in the seed cost. The elasticity of the significant parameter estimates viz. NPK fertilizer cost, cost of urea fertilizer, cost of herbicides, rental fees and output $(\mathrm{kg})$ being positive implies that the total cost increase monotonically with an increase in the prices of these inputs and the only output parameter included in the SFC. Thus, a percent increase in the prices of NPK fertilizer, urea fertilizer, herbicides and land rental fee each would increase the total cost of production by $33.39 \%, 43.22 \%, 36.56 \%$ and $29.48 \%$, respectively. Besides, a percent increase in the output level of rice would increase the total cost by $35.86 \%$. The non-significance of the human labour and depreciation on capital items implied that the farmers relied on excess available family labour which is free of cost and incurred negligible costs on the fixed capital as they used primitive implements in the production of rice.

It was observed that the farmers despite operating in the rational stage i.e. decreasing return to scale they were experiencing diseconomies of scale as indicated by the economies of scale (ES) index of -3.84. This did not come as a surprise as these farmers are resource-poor who cultivate rice on smallscale basis, thus an increase in the output will increase the cost of production. This finding is contrary to the Schultz's efficient hypothesis for poor farmers, that in their resource allocation behaviour under traditional agricultural setting they are efficient giving the available technology at their disposal (Schultz, 1964; Ogundari et al., 2006; Sadiq and Singh, 2016).

Furthermore, it was observed that cost efficiency is influenced by sickness of household member, household size, farm size and number of language spoken as evident from their respective parameter estimates which were different from zero at $10 \%$ degree of freedom. The positive significance of the coefficient for sickness of household member implied that a farmer with a health challenge affecting his household incurred extra labour cost due to substitution of family labour with hired labour, thus affecting the cost efficiency of the farmer. Thus, a farm family having a sick fellow will have his/her cost inefficiency increased by $0.214 \%$. The negative significance of the household size coefficient implied that farmers with large household size composed of able-bodied people incurred less cost on labour due to access to free labour, thus an increase in their cost efficiency, Thus, a unit increase in the farm family household size by one person would lead to a decrease in his/her cost inefficiency by $0.075 \%$. The positive significance of the farm size revealed that farmers with large farm size experienced diseconomies of scale, thus affecting their cost efficiency. Therefore, the implication of a unit increase in the farm size by one hectare would lead to an increase in cost inefficiency by $1.655 \%$. The negative significance of the parameter estimates for language spoken implied that farmers who understand or speak more than one lingua had access to information concerning innovative and appropriate practices of allocation of farm inputs, thus making them more cost efficiency than their counterpart who understands only one language. Thus, the tendency of a farmer to speak more than one language would increase his/her cost efficiency by $0.469 \%$.

A perusal of the cost efficiency scores showed the average cost efficiency to be 1.218 while the best and worse cost inefficiency scores were 1.025 and 2.305, respectively (Table 4).Therefore, the implication is that the average, best and worse cost inefficiency farmers incurred an extra cost of $21.8 \%$, $2.5 \%$ and $130.5 \%$ respectively relative to the best practiced farm producing the same output and facing the same technology at their disposal. In nominal value, it translates into $\$ 20600.51, \$ 1484.39$ and $\$ 107948.10$ for the average, best and worst inefficient farms respectively (Table 5). The individualwise results showed the potential minimum cost expected of each farm and the wasted incurred cost that need to be averted for the inefficiency farms so as to optimize profit in the short-run (Table 5). The frequency distribution of the cost efficiency scores showed none of the farmers to be on the frontier as evident by their respective cost efficiency scores which were above the frontier score of 1.00. It was observed that majority (53.6\%) of the farmers had their efficiency scores close to the frontier level while very few $(3.6 \%)$ of the respondents recorded an efficiency scores that are farther from the frontier surface. Similar result was found by Yakubu (2017) in his study on economic efficiency of small-scale rice farmers in Kwara State of Nigeria. However, in maize crop, Sadiq and Singh (2016); Paudel and Matsuoka (2009) and Ogundari et al. (2006) observed similar result in their respective studied areas.

Table 2. MLE of the stochastic cost frontier of IFAD rice farmers 


\begin{tabular}{|c|c|c|c|}
\hline Variable & Coefficient & Standard error & t-statistic \\
\hline \multicolumn{4}{|l|}{ Deterministic model } \\
\hline Constant & 1.06895 & 0.99335 & $1.076^{\mathrm{NS}}$ \\
\hline Seed $(\#)$ & -0.24035 & 0.078993 & $3.043 * * *$ \\
\hline NPK fertilizer ( & 0.33385 & 0.134949 & $2.473 * *$ \\
\hline Urea fertilizer ( & 0.43218 & 0.123087 & $3.511 * * *$ \\
\hline Herbicides ( & 0.36561 & 0.141361 & $2.586^{* *}$ \\
\hline Human labour labour ( $¥)$ & 0.119099 & 0.074115 & $1.606^{\mathrm{NS}}$ \\
\hline Rent value of land ( & 0.294837 & 0.0885465 & $3.329 * * *$ \\
\hline Depreciation on cap. ( $\mathbb{N}$ & 0.042828 & 0.0427875 & $1.001^{\mathrm{NS}}$ \\
\hline Output (kg) & 0.3585499 & 0.196904 & $1.820 *$ \\
\hline \multicolumn{4}{|l|}{ Inefficiency model } \\
\hline Constant & -3.00142 & 1.05781 & $2.837 * * *$ \\
\hline Education & 0.032828 & 0.03319 & $0.988^{\mathrm{NS}}$ \\
\hline Illness of member & 0.21368 & 0.11938 & $1.789 *$ \\
\hline Extension visit & 0.03062 & 0.058304 & $0.525^{\mathrm{NS}}$ \\
\hline Access to credit & -0.08388 & 0.3113 & $0.269^{\mathrm{NS}}$ \\
\hline Age & 0.009622 & 0.02615 & $0.368^{\mathrm{NS}}$ \\
\hline Household size & -0.074497 & 0.05432 & $1.372^{\mathrm{NS}}$ \\
\hline Income & $0.35555 \mathrm{E}-06$ & $0.41535 \mathrm{E}-06$ & $0.856^{\mathrm{NS}}$ \\
\hline Farm size & 1.65495 & 0.31176 & $5.308 * * *$ \\
\hline Farming Experience & -0.008799 & 0.02537 & $0.347^{\mathrm{NS}}$ \\
\hline Non-farm income & 0.051108 & 0.33811 & $0.151^{\mathrm{NS}}$ \\
\hline Language spoken & -0.46844 & 0.27972 & $1.675^{*}$ \\
\hline \multicolumn{4}{|l|}{ Variance parameters } \\
\hline Sigma-squared $\left(\sigma^{2}\right)$ & 0.15649 & 0.04682 & $3.342 * * *$ \\
\hline $\operatorname{Gamma}(\gamma)$ & 0.86307 & 0.044471 & $1.941 * *$ \\
\hline
\end{tabular}

Source: Field survey, 2018.

$*, * *, * * *$ and ${ }^{\mathrm{NS}}$ means significance at $10 \%, 5 \%, 1 \%$ and non-significant respectively.

Table 3. Generalized likelihood ratio test of hypothesis for parameters of SCFF

\begin{tabular}{clllc}
\hline$H_{o}$ & Log likelihood function & $\lambda$ & Critical (5\%) & Decision \\
$\gamma=0$ & 23.602 & 21.05 & 16.91 & $\gamma \neq 0$ \\
\hline
\end{tabular}

Source: Field survey, 2018.

Table 4. Frequency distribution of cost efficiency scores

\begin{tabular}{lll}
\hline Efficiency level & Frequency & Relative efficiency $\%$ \\
\hline $1.00-1.09$ & 59 & 53.63636 \\
$1.10-1.19$ & 18 & 16.36364 \\
$1.20-1.29$ & 10 & 9.090909 \\
$1.30-1.39$ & 4 & 3.636364 \\
$1.40-1.49$ & 4 & 3.636364 \\
$1.50-1.59$ & 3 & 2.727273 \\
$1.60-1.69$ & 3 & 2.727273 \\
$1.70-1.79$ & 2 & 1.818182 \\
$1.80-1.89$ & 2 & 1.818182 \\
$1.90-1.99$ & 1 & 0.909091 \\
$\geq 2.00$ & 4 & 3.636364 \\
\hline Total & 110 & 100 \\
Mean & 1.218 & \\
Maximum & 2.305 & \\
Minimum & 1.025 & \\
Standard deviation & 0.271 & \\
\hline
\end{tabular}

Source: Field survey, 2018. 
Table 5. Individual-wise CES, Actual cost, Frontier cost and wasted cost

\begin{tabular}{|c|c|c|c|c|c|c|c|c|c|c|c|}
\hline Farm & CES & Actual & Frontier & WC & $\% \mathrm{WC}$ & Farm & CES & Actual & Frontier & WC & $\% \mathrm{WC}$ \\
\hline FM1 & 1.147 & 101878 & 88821.27 & 13056.73 & 12.81604 & FM31 & 1.051 & 81028 & 77096.1 & 3931.901 & 4.852521 \\
\hline FM2 & 1.113 & 80138 & 72001.8 & 8136.203 & 10.15274 & FM32 & 1.069 & 87877.5 & 82205.33 & 5672.168 & 6.45463 \\
\hline FM3 & 1.662 & 251170 & 151125.2 & 100044.8 & 39.83153 & FM33 & 1.058 & 88180 & 83345.94 & 4834.064 & 5.482042 \\
\hline FM4 & 1.078 & 117802 & 109278.3 & 8523.707 & 7.235622 & FM34 & 1.103 & 109225 & 99025.39 & 10199.61 & 9.338169 \\
\hline FM5 & 1.466 & 172935 & 117963.8 & 54971.15 & 31.78718 & FM35 & 1.449 & 162670 & 112263.6 & 50406.37 & 30.98689 \\
\hline FM6 & 1.066 & 118750 & 111397.7 & 7352.251 & 6.19137 & FM36 & 1.051 & 98844 & 94047.57 & 4796.426 & 4.852521 \\
\hline FM7 & 1.064 & 110810 & 104144.7 & 6665.263 & 6.015038 & FM37 & 1.087 & 101500 & 93376.26 & 8123.735 & 8.00368 \\
\hline FM8 & 1.092 & 125364 & 114802.2 & 10561.8 & 8.424908 & FM38 & 1.087 & 117453 & 108052.4 & 9400.562 & 8.00368 \\
\hline FM9 & 2.123 & 303630 & 143019.3 & 160610.7 & 52.89684 & FM39 & 1.056 & 96130 & 91032.2 & 5097.803 & 5.30303 \\
\hline FM10 & 1.495 & 206164 & 137902.3 & 68261.66 & 33.11037 & FM40 & 1.06 & 90705 & 85570.75 & 5134.245 & 5.660377 \\
\hline FM11 & 1.058 & 106340 & 100510.4 & 5829.603 & 5.482042 & FM41 & 1.077 & 84087 & 78075.21 & 6011.791 & 7.149489 \\
\hline FM12 & 1.07 & 95722.77 & 89460.54 & 6262.237 & 6.542056 & FM42 & 1.395 & 101340 & 72645.16 & 28694.84 & 28.31541 \\
\hline FM13 & 1.109 & 114145.5 & 102926.6 & 11218.99 & 9.828674 & FM43 & 1.074 & 90420 & 84189.94 & 6230.056 & 6.89013 \\
\hline FM14 & 1.141 & 99182.77 & 86926.18 & 12256.59 & 12.35758 & FM44 & 1.039 & 45610 & 43897.98 & 1712.021 & 3.753609 \\
\hline FM15 & 2.016 & 277590 & 137693.5 & 139896.5 & 50.39683 & FM45 & 1.051 & 68245 & 64933.4 & 3311.603 & 4.852521 \\
\hline FM16 & 1.227 & 124260 & 101271.4 & 22988.61 & 18.50041 & FM46 & 1.067 & 58396 & 54729.15 & 3666.853 & 6.279288 \\
\hline FM17 & 1.039 & 66505 & 64008.66 & 2496.338 & 3.753609 & FM47 & 1.035 & 74920 & 72386.47 & 2533.527 & 3.381643 \\
\hline FM18 & 1.121 & 109085.5 & 97310.92 & 11774.62 & 10.79393 & FM48 & 1.074 & 102725 & 95647.11 & 7077.886 & 6.89013 \\
\hline FM19 & 1.57 & 215878 & 137501.9 & 78376.09 & 36.30573 & FM49 & 1.095 & 83250 & 76027.4 & 7222.603 & 8.675799 \\
\hline FM20 & 1.508 & 165909 & 110019.2 & 55889.77 & 33.687 & FM50 & 1.04 & 85190 & 81913.46 & 3276.538 & 3.846154 \\
\hline FM21 & 1.103 & 114570 & 103871.3 & 10698.74 & 9.338169 & FM51 & 1.111 & 77755 & 69986.5 & 7768.501 & 9.990999 \\
\hline FM22 & 1.395 & 203565 & 145924.7 & 57640.27 & 28.31541 & FM52 & 1.656 & 121800 & 73550.72 & 48249.28 & 39.61353 \\
\hline FM23 & 1.17 & 139235 & 119004.3 & 20230.73 & 14.52991 & FM53 & 1.1 & 84050 & 76409.09 & 7640.909 & 9.090909 \\
\hline FM24 & 1.069 & 84440 & 78989.71 & 5450.29 & 6.45463 & FM54 & 1.073 & 97500 & 90866.73 & 6633.271 & 6.803355 \\
\hline FM25 & 1.086 & 100820 & 92836.1 & 7983.904 & 7.918969 & FM55 & 2.021 & 151600 & 75012.37 & 76587.63 & 50.51954 \\
\hline FM26 & 1.047 & 96930 & 92578.8 & 4351.203 & 4.489016 & FM56 & 1.11 & 104945.5 & 94545.54 & 10400.01 & 9.90991 \\
\hline FM27 & 1.046 & 76930 & 73546.85 & 3383.155 & 4.397706 & FM57 & 1.078 & 111525 & 103455.5 & 8069.527 & 7.235622 \\
\hline FM28 & 1.417 & 159760 & 112745.2 & 47014.76 & 29.42837 & FM58 & 1.098 & 110165 & 100332.4 & 9832.577 & 8.925319 \\
\hline FM29 & 1.855 & 209695 & 113043.1 & 96651.87 & 46.09164 & FM59 & 1.058 & 95145.55 & 89929.63 & 5215.918 & 5.482042 \\
\hline FM30 & 1.074 & 95280 & 88715.08 & 6564.916 & 6.89013 & FM60 & 1.15 & 111310 & 96791.3 & 14518.7 & 13.04348 \\
\hline
\end{tabular}

Source: Field survey, 2018. 
YYÜ TAR BIL DERG (YYU J AGR SCI) 31 (2): 268-276

Sadiq et al.,/ Cost Efficiency Status of Rice Farmers Participating in IFAD/VCD Programme in Niger State of Nigeria

Table 5 (continuation). Individual-wise CES, Actual cost, Frontier cost and wasted cost

\begin{tabular}{|c|c|c|c|c|c|c|c|c|c|c|c|}
\hline Farm & CES & Actual & Frontier & WC & $\% \mathrm{WC}$ & Farm & CES & Actual & Frontier & WC & $\% \mathrm{WC}$ \\
\hline FM61 & 1.063 & 115645.5 & 108791.7 & 6853.875 & 5.926623 & FM87 & 1.05 & 77760 & 74057.14 & 3702.857 & 4.761905 \\
\hline FM62 & 1.044 & 64900 & 62164.75 & 2735.249 & 4.214559 & FM88 & 1.045 & 75700 & 72440.19 & 3259.809 & 4.30622 \\
\hline FM63 & 1.034 & 64540 & 62417.79 & 2122.205 & 3.288201 & FM89 & 1.056 & 79950 & 75710.23 & 4239.773 & 5.30303 \\
\hline FM64 & 1.025 & 60860 & 59375.61 & 1484.39 & 2.439024 & FM90 & 1.049 & 61280 & 58417.54 & 2862.459 & 4.671115 \\
\hline FM65 & 1.048 & 68300 & 65171.76 & 3128.244 & 4.580153 & FM91 & 1.134 & 108770 & 95917.11 & 12852.89 & 11.81658 \\
\hline FM66 & 1.168 & 99485.55 & 85175.98 & 14309.56 & 14.38356 & FM92 & 1.0617 & 85140 & 80192.14 & 4947.855 & 5.811434 \\
\hline FM67 & 1.075 & 86700 & 80651.16 & 6048.837 & 6.976744 & FM93 & 1.134 & 120900 & 106613.8 & 14286.24 & 11.81658 \\
\hline FM68 & 1.353 & 109845.5 & 81186.66 & 28658.89 & 26.09017 & FM94 & 1.056 & 81600 & 77272.73 & 4327.273 & 5.30303 \\
\hline FM69 & 1.085 & 105740 & 97456.22 & 8283.779 & 7.834101 & FM95 & 1.047 & 78780 & 75243.55 & 3536.447 & 4.489016 \\
\hline FM70 & 1.201 & 84220 & 70124.9 & 14095.1 & 16.73605 & FM96 & 1.134 & 125500 & 110670.2 & 14829.81 & 11.81658 \\
\hline FM71 & 1.034 & 58000 & 56092.84 & 1907.157 & 3.288201 & FM97 & 1.0559 & 87690 & 83047.64 & 4642.363 & 5.294062 \\
\hline FM72 & 1.089 & 95620 & 87805.33 & 7814.674 & 8.172635 & FM98 & 1.967 & 196400 & 99847.48 & 96552.52 & 49.16116 \\
\hline FM73 & 1.39 & 114955 & 82701.44 & 32253.56 & 28.05755 & FM99 & 1.299 & 278400.8 & 214319.3 & 64081.47 & 23.01771 \\
\hline FM74 & 1.041 & 62940 & 60461.1 & 2478.905 & 3.938521 & FM100 & 2.305 & 190667 & 82718.87 & 107948.1 & 56.61605 \\
\hline FM75 & 1.099 & 106990 & 97352.14 & 9637.862 & 9.008189 & FM101 & 1.092 & 74390 & 68122.71 & 6267.289 & 8.424908 \\
\hline FM76 & 1.737 & 182280 & 104939.6 & 77340.45 & 42.42948 & FM102 & 1.274 & 123310 & 96789.64 & 26520.36 & 21.50706 \\
\hline FM77 & 1.057 & 105510 & 99820.25 & 5689.754 & 5.392621 & FM103 & 1.1595 & 145000 & 125053.9 & 19946.1 & 13.75593 \\
\hline FM78 & 1.273 & 153140 & 120298.5 & 32841.49 & 21.4454 & FM104 & 1.2052 & 161880 & 134318 & 27562.04 & 17.02622 \\
\hline FM79 & 1.064 & 90017 & 84602.44 & 5414.556 & 6.015038 & FM105 & 1.861 & 154638 & 83094.04 & 71543.96 & 46.26545 \\
\hline FM80 & 1.058 & 80838 & 76406.43 & 4431.573 & 5.482042 & FM106 & 1.601 & 141230 & 88213.62 & 53016.38 & 37.53904 \\
\hline FM81 & 1.2495 & 146260 & 117054.8 & 29205.18 & 19.96799 & FM107 & 1.101 & 90338 & 82050.86 & 8287.137 & 9.173479 \\
\hline FM82 & 1.222 & 125220 & 102471.4 & 22748.64 & 18.16694 & FM108 & 1.297 & 112458 & 86706.25 & 25751.75 & 22.899 \\
\hline FM83 & 1.047 & 70540 & 67373.45 & 3166.552 & 4.489016 & FM109 & 1.282 & 145330 & 113361.9 & 31968.07 & 21.99688 \\
\hline FM84 & 1.515 & 146092 & 96430.36 & 49661.64 & 33.9934 & FM110 & 1.738 & 142564 & 82027.62 & 60536.38 & 42.4626 \\
\hline FM85 & 1.078 & 93040 & 86307.98 & 6732.022 & 7.235622 & Mean & 1.218 & 115098.3 & 94497.77 & 20600.51 & 17.89819 \\
\hline FM86 & 1.077 & 91380 & 84846.8 & 6533.203 & 7.149489 & & & & & & \\
\hline
\end{tabular}

Source: Field survey, 2018.

Note: $\mathrm{CES}=$ Cost efficiency score; $\mathrm{WC}=$ Wasted cost. 


\section{Discussion and Conclusion}

From the foregoing findings, it can be inferred that the farmers were not efficient in minimizing their farm costs which was largely due to health challenge of the farm family and diseconomies of scale which owed to their mode of operation i.e. small-scale holdings. Furthermore, all the sampled farms experienced cost wastage relative to the best practiced farm producing the same output using the same available technology in the studied area. Therefore, it was recommended that both public and private institutions should sensitize the farmers on the importance of health preventive measures, improvise basic health centres with adequate staffing of health personnel, and affordable and subsidized medications. In addition, the farmers should be enlighten on the importance of social capital viz. cooperative marketing in order to benefit from pecuniary advantages, thus addressing the problem of diseconomies of scale.

\section{References}

Battese, G.E., \& Coellli, T.J. (1995). A model for technical inefficiency effects in stochastic frontier production for panel data. Empirical Economics, 20, 325-345.

Ogundari, K., Ojo, S.O., \& Ajibefun, I.A. (2006). Economics of scale and cost efficiency in small-scale maize production: Empirical evidence from Nigeria. Journal of Social Sciences, 13(2), 131-136.

Paudel, P., \& Matsuoka, A. (2009). Cost efficiency estimates of maize production in Nepal: A case study of the Chitwan District. Agricultural Economics-Czech, 55(3), 139-148.

Sadiq, M.S., \& Isah, M.A. (2015).Neoclassical test of cost efficiency in sorghum production among

small- scale farmers in Niger State, Nigeria. International Journal of Tropical Agriculture, 3(2), 423431.

Sadiq, M.S., \& Samuel, P.E. (2016). Lucid investigation of cost efficiency of small-scale poultry broiler farms in Niger State of Nigeria. International Journal of Innovative Research and Review, 4(4), 9-23.

Sadiq, M.S., \& Singh, I.P. (2016). Empirical analysis of economics of scale and cost efficiency of small-scale maize production in Niger state, Nigeria. Indian Journal of Economics and Development, 12(1), 55-63.

Shultz, T. W. (1964). Transforming Traditional Agriculture. New Haven: Yale University Press.

Yakubu, G. (2017). Economic efficiency of small-scale rice farmers in Kwara State of Nigeria. A B.Tech. Thesis submitted to the Department of Agricultural Economics and Extension Technology, Federal University of Technology, Minna, Nigeria 